\title{
Isolation and identification of bioactive compounds from kernel seed cake of the mango (Mangifera indica Lam)
}

\author{
Amian B. B. KASSI ${ }^{1,2}$, Yaya SORO ${ }^{1 *}$, Bamba FANTE ${ }^{2}$, Koffi Julien GOLLY ${ }^{3}$, \\ Siaka SORHO ${ }^{1}$, Amadou Seikou TOURE ${ }^{2}$ and Jean-Marie COUSTARD ${ }^{4}$ \\ ${ }^{1}$ Laboratoire des Procédés Industriels de Synthèse, de l'Environnement et des Energies Nouvelles, Institut \\ National Polytechnique Félix Houphouët-Boigny, BP 991 Yamoussoukro, Côte d'Ivoire. \\ ${ }^{2}$ Laboratoire de Chimie Organique Structurale, Université Félix Houphouët-Boigny, \\ 22 BP582 Abidjan 22, Côte d'Ivoire. \\ ${ }^{3}$ Laboratoire de Bactériologie - Virologie de l'Institut Pasteur de Côte d'Ivoire, \\ 01 BP 490 Abidjan 01, Côte d'Ivoire. \\ ${ }^{4}$ Laboratoire "Synthèse et Réactivité des Substances Naturelles", UMR 6514 \\ 40, Avenue du Recteur Pineau, F-86022 Poitiers, France. \\ "Corresponding author; E-mail: soro_y@yahoo.fr; Tel: (00225)07716766 Fax: (00225)30640406
}

\begin{abstract}
The ethanol extract and ethyl acetate fraction of Mangifera indica kernel seed cake inhibited the growth of Staphylococcus aureus and Pseudomonas aeruginosa. The bioactive compounds were isolated and identified by NMR, UV and mass spectrometry as methyl gallate, gallic acid and penta- $O$-galloylglucose. The isolated methyl gallate and penta- $O$-galloylglucose also showed significant antibacterial activities against Staphylococcus aureus and Pseudomonas aeruginosa.

(C) 2014 International Formulae Group. All rights reserved.
\end{abstract}

Keywords: Mangifera indica, kernel seed cake, antibacterial activity, gallic acid, penta- $O$-galloylglucose, methyl gallate.

\section{INTRODUCTION}

Mango (Mangifera indica Lam), which belongs to the family of Anacardiaceae, is one of the most popular tropical fruits, followed by banana, pineapple, papaya, and avocado (FAO, 2002). In food processing industry after the extraction of mango pulp and kernel butter, a considerable quantity of kernel seed cake is discarded as waste (Ahmed et al., 2007).

The mango plant has been the focus of attention of many researchers for potent antioxidants. Mango parts, such as stem bark, leaves, and pulp are known for various biomedical applications, including antioxidative and free radical scavenging (Gabino et al., 2008), and anticancer activities (Susan et al., 2006).

Mango seeds are used traditionally against gastric pathogens, especially in children treatment, or in anti-diarrhoeal cure (Sairam et al., 2003). Ethanolic or methanolic extract of mango seed showed antibacterial and antioxidant activities (Ahmed et al., 2007) 
as well as antimicrobial ones (Thoshihide et al., 2000).

Mango kernel butter and cocoa butter were almost identical in several of their constants, as triglycerides, fatty acids, effects on taste and odour (Djenontin et al., 2006).

Aqueous-methanolic extracts of pulp, peel and seed kernels were a rich source of phenolic compounds (Ribeirio et al., 2008 ; Sunday, 2000), though several investigations have been made on the medicinal properties of mango fruit pulp and peel (Hana et al., 2010).

In the present paper, we report the isolation and identification of phenolics compounds of mango kernel seed cake, and we evaluate its antibacterial activity. To our best knowledge, no study has been carried out on the identification of the bioactive compounds obtained by fractionation of ethanolic bioactive fractions of mango kernel seed cake.

\section{MATERIALS AND METHODS \\ Background}

NMR experiments were recorded with a Bruker Avance 400 spectrometer at 400 $\mathrm{MHz}$ for ${ }^{1} \mathrm{H}$ and at $100 \mathrm{MHz}$ for ${ }^{13} \mathrm{C}$ at $23{ }^{\circ} \mathrm{C}$. The spectra were acquired in $\mathrm{MeOH}-\mathrm{d}_{4}$ or DMSO- $\mathrm{d}_{6}$. The chemical shifts are expressed in part per million (ppm) relative to TMS $(\delta=$ $0 \mathrm{ppm}$ ) and the coupling constant $\mathbf{J}$ in hertz $(\mathrm{Hz})$ or residual solvent peak. Flash column chromatography was performed using Macherey-Nagel Silica gel $60(15-40 \mu \mathrm{m})$. TLC plates (Macherey-Nagel, ALUGRAM ${ }^{\circledR}$ $\mathrm{SILG} / \mathrm{UV}_{254}, 0,2 \mathrm{~mm}$ silica gel $60 \AA$ ) were visualized under $254 \mathrm{~nm}$ UV light and/or by dipping the TLC plate into a solution of phosphomolibdic acid $(3 \mathrm{~g})$ in EtOH $(100 \mathrm{~mL})$ followed by heating with a heat gum. ESI-MS were recorded on a Shimadzu GC MS-QP 2010 Gas Chromatograph Mass Spectrometer and reported in units of mass over charge $(\mathrm{m} / \mathrm{z})$. The mode of ionization used was electron-impact one (EI, $70 \mathrm{eV}$ ). Highresolution electrospray mass spectra (HRESIMS) in the positive ion mode were performed using a Q-TOF Ultima Global hybrid quadruple time-of-flight instrument (WatersMicromass).

\section{High-Performance Liquid Chromatography (HPLC) Analysis}

Analytic HPLC were performed using a RP-18 $(5 \mu \mathrm{m})$ Lichro CART® 150-4.6 mm at $25{ }^{\circ} \mathrm{C}$. The binary elution system was composed of acetonitrile (solvent A) and $0.2 \%$ TFA/water (solvent B). Separations were performed at room temperature by solvent gradient elution: 10-20\% B during $40 \mathrm{~min}, 20-$ $30 \%$ B during $5 \mathrm{~min}, 30-40 \%$ B during $5 \mathrm{~min}$, $40-45 \%$ B during $5 \mathrm{~min}$ and turning to the initial conditions (10\% B) during 5 min to reequilibrate the column prior to another run. The flow rate for both analysis and washing cycles was $0.8 \mathrm{~mL} / \mathrm{min}$. The concentration of each sample was $0.1 \mathrm{mg} / \mathrm{mL}$ in methanol, detection wavelengths being 254, 280, 325 and $530 \mathrm{~nm}$.

\section{Plant material}

Ripe fruits of Mangifera indica were collected in April 2009 at the end of dry season in Yamoussoukro city in the center of Côte d'Ivoire. A voucher sample was identified by Prof. Aké-Assi Laurent, Faculty of Science and Technology, Félix HouphouëtBoigny University where the sample was deposited. The seed kernel was isolated from the fruits, dried during 5 days at $40{ }^{\circ} \mathrm{C}$ and 2 days at $50{ }^{\circ} \mathrm{C}$. The seed kernels were powdered and stored at $-10{ }^{\circ} \mathrm{C}$ until use.

\section{Phytochemical tests}

A phytochemical screening was performed for testing the presence of secondary metabolites. The tests were carried out according to Harborne method (Harborne, 1998). The chemical constituents of the seed kernel cake extracts were tested for the presence of flavonoids (cyanidine test), anthraquinones (ammonium test), alkaloids (Dragendorff test), terpenoids and steroids (Liberman Buchard test), tannins (ferric chloride test), saponins (formation of 
persistent foams during plant extraction or during concentration of plant extract).

\section{Extraction procedure}

The dried seed kernels powder $(500 \mathrm{~g})$ was extracted to exhaustion with Hexane (3x1 L) at room temperature. The residue (obtained cake) was extracted with $70 \% \mathrm{EtOH}(3 \times 1 \mathrm{~L})$ at room temperature at constant stirring during 24 hours. After filtration on cotton then watmann paper, the extract was concentrated under reduced pressure at $40{ }^{\circ} \mathrm{C}$ to afford the ethanolic extract $(85 \mathrm{~g})$. The residue was suspended in water and partitioned successively with dichloromethane (3 x 200 $\mathrm{mL})$ and ethyl acetate (3 x $200 \mathrm{~mL})$. The obtained extracts were separately dehydrated with anhydrous sodium sulfate and evaporated under vacuum after filtration to afford dichloromethane $\left(\mathrm{CH}_{2} \mathrm{Cl}_{2}\right)$ extract $(1.27 \mathrm{~g})$ and ethyl acetate (AcOEt) extract (6.54 g).

\section{Isolation and purification of ethyl acetate fraction}

The ethyl acetate fraction (6.54 g) of Mangifera indica kernel seed cake was subjected to flash chromatography on silica gel 60 with solvents gradients $\mathrm{CH}_{2} \mathrm{Cl}_{2}$-AcOEt and AcOEt-MeOH to give 5 fractions $\left(\mathrm{F}_{1}-\mathrm{F}_{5}\right)$. Fraction $\mathrm{F}_{2}$ was purified by flash chromatography on silica gel 60 , eluting with $\mathrm{CH}_{2} \mathrm{Cl}_{2}-\mathrm{MeOH}$ (10-1) to give compound 1 (457 mg). Fraction $\mathrm{F}_{4}$ was also purified by flash chromatography on silica gel 60, eluting with $\mathrm{CH}_{2} \mathrm{Cl}_{2}-\mathrm{MeOH}$ (10-2) to give compounds 2 (261 mg) and 3 (986 mg). The different fractions were checked by TLC and HPLC. Another aliquot was dissolved in Methanol-d4 and analyzed by NMR for chemical structure determination of each compound. The ${ }^{1} \mathrm{H}$ and ${ }^{13} \mathrm{C}$ NMR assignments of the three compounds were determined on the basis of the ${ }^{1} \mathrm{H},{ }^{13} \mathrm{C},{ }^{1} \mathrm{H}-{ }^{1} \mathrm{H}$ COSY, HMQC, and $\mathrm{HMBC}$ spectra.

\section{Microorganism strains}

The microorganism strains used for biological tests were obtained from the
Antibiotics Unit of Natural Substances and Survey of Resistance of Micro-organisms for Anti-Infective (ASSURMI), Department of Bacteriology at Pasteur Institute of Côte d'Ivoire (IPCI). The strains used in the present work were: Staphylococcus aureus sensitive to methicillin ( $\mathbf{S a} \mathbf{S}$ ), Staphylococcus aureus resistant to methicillin (Sa R), referenced strains of Staphylococcus aureus ATCC 25923 (Sa AT), Pseudomonas aeruginosa sensitive to ceftazidime and imipenem $(\boldsymbol{P a} \mathbf{S})$, Pseudomonas aeruginosa resistant to ceftazidime and imipenem $\left(\begin{array}{ll}\boldsymbol{P a} & \mathbf{R}\end{array}\right)$ and referenced strains of Pseudomonas aeruginosa ATCC 27853 (Pa AT).

\section{Efficiency test substances}

The efficiency test was used to detect biological activity of a substance. For this test, the agar and Mueller Hinton broth were the main culture media (Zakaria et al., 2006a). The mixture of DMSO / distilled water in proportion 1:1 (v/v) was used as solvent to prepare the solution of seed kernel cake extracts. Biorad ${ }^{\circledR}$ non-impregnated discs of 6 $\mathrm{mm}$ diameter were also used. The tests were performed on bacterial inoculums of $5.10^{6}$ $\mathrm{CFU} / \mathrm{mL}$. Each disc was impregnated with 40 $\mu \mathrm{L}$ of extract or fractions solutions at 200 $\mathrm{mg} / \mathrm{mL}$ concentration. The choice of 200 $\mathrm{mg} / \mathrm{mL}$ concentration for this test was literature guided. After drying, the discs were placed on the agar previously seeded with micro bacterial strains and incubated at $37{ }^{\circ} \mathrm{C}$ during the period from 18 to 24 hours (Zakaria et al., 2006a). The observation of an inhibition zone reflected the existence of antimicrobial activity. Observation of an inhibition zone can be used to judge the efficiency of substances in extract or fractions. Control tests were carried out using impregnated discs with $40 \mu \mathrm{L}$ of appropriate solvent used to prepare extract or fractions.

To confirm the resistance of bacteria, tests on young colonies using oxacillin (OX-5 
$\mu \mathrm{g})$ and cefoxitin (FOX-30 $\mu \mathrm{g}$ ) for S. aureus and ceftazidime (CAZ-30 $\mu \mathrm{g})$ and imipenem (IMP $10 \mathrm{mg}$ ) for $P$. aeruginosa were performed under the same conditions.

\section{Determination of antimicrobial activity}

Antimicrobial activity of the isolated compounds from Mangifera indica seed kernel cake was evaluated via the microdilution broth method (Oussou et al., 2008). Concentration range of compounds was prepared by the method of double dilution with the concentrations ranging from 25 to $0.0244 \mathrm{mg} / \mathrm{mL}$ for each compound. The antimicrobial tests were performed by introducing into a series of hemolysis tubes 1 $\mathrm{mL}$ of the solution of compound $\mathbf{1 - 3}$ and $1 \mathrm{~mL}$ of bacterial inoculums (Moroh et al., 2007). At the same time, in control tube, $1 \mathrm{~mL}$ of the solvent used to solve the extract (DMSO / distilled water to $1: 13 \mathrm{v} / \mathrm{v}$ ) and $1 \mathrm{~mL}$ of bacterial inoculums were introduced. All the tubes were incubated at $37{ }^{\circ} \mathrm{C}$ for 18 to 24 hours.

The results of antimicrobial screening were evaluated with naked eye estimating transparency/turbidity of the test tubes at daylight (Koné et al., 2006). The transparency of the tubes indicated the antimicrobial effect of the tested extract, while turbidity shows its ineffectiveness (a sign of bacterial growth). The Minimum Inhibitory Concentration (MIC) will correspond to the concentration of the extract in the first tube with a clear content.

\section{RESULTS}

\section{Phytochemical screening}

Phytochemical screening tests of the air-dried kernel seed cake of Mangifera indica evaluated in this work revealed appreciable amount of tannins, triterpenes, steroids and alkaloids and traces of flavonoids, saponins, anthraquinones (Table 1).

\section{Determination of antimicrobial activity}

The ethanolic (70\%) extract of the airdried Mangifera indica kernel seed cake was partitioned between $\mathrm{CH}_{2} \mathrm{Cl}_{2}$ and water, and then between AcOEt and water.

The tests of efficiency (Golly et al., 2012) conducted prior to the determination of microbiological parameters of extract at 200 $\mathrm{mg} / \mathrm{mL}$ give the results summarized in Table 2. This preliminary investigation on the antimicrobial activities of ethanolic extract and ethyl acetate fraction was found to be significantly sensitive against Staphylococcus aureus and moderately sensitive against Pseudomonas aeruginosa.

These interesting preliminary results on the antibacterial activity of mango seed kernel cake encouraged us to isolate and test the biomolecules.

\section{Isolation and identification of major compounds}

The HPLC analysis (Figure 1) of the ethyl acetate fraction Mangifera indica seed kernel indicated the presence of three (3) majors compounds (compounds 1, 2 and $\mathbf{3}$ ).

A preliminary study of the UV spectral (Table 3 ) of the peaks gave a first indication of the family of phenolic compounds (Pretsch et al., 2009). UV spectra of compounds $\mathbf{1 , 2}$ and $\mathbf{3}$ showed an absorbance bands at 270 , 271 and $279 \mathrm{~nm}$.

The ethyl acetate fraction was purified by chromatography on silica gel to obtain compounds $\mathbf{1}, \mathbf{2}$ and $\mathbf{3}$ as crystalline compounds. The UV, ${ }^{1} \mathrm{H}$ NMR, ${ }^{13} \mathrm{C}$ NMR and EI-MS spectral data with reported values lead to the identification of compound $\mathbf{1 , 2}$ and $\mathbf{3}$ as Methyl gallate, Gallic acid and Penta- $O$ galloylglucose.

Compound 1: Methyl gallate; Yellow powder; HPLC $\mathrm{R}_{\mathrm{t}} 14.30 \mathrm{~min}$; UV vis $\lambda_{\max }: 271 \mathrm{~nm}$ (methanol) ; HREI-MS $\mathrm{m} / \mathrm{z} 207.0271$ $[\mathrm{M}+\mathrm{Na}]^{+} ; \mathrm{m} / \mathrm{z} 184.0271[\mathrm{M}]^{+}, \mathbf{C}_{8} \mathbf{H}_{8} \mathbf{O}_{5}$ (calcd 
184.0372); ${ }^{13} \mathrm{C}$ NMR (100 MHz, Methanold4): 121.43 (C-1), 110.02 (C-2/C-6), 146.51 (C-3/C-5), 139.77 (C-4), $169.02(\mathrm{C}=\mathrm{O}), 61.68$ $\left(\mathrm{O}-\mathrm{CH}_{3}\right) .{ }^{1} \mathrm{H}$ NMR (400 MHz, Methanold4):7.06 (H-2/H-6, d, J=1.7Hz), 3.83(O- $\mathrm{CH}_{3}$, $\mathrm{s})$.

Compound 2: Gallic acid; White powder; HPLC $R_{t} 3.91$ min; UV vis $\lambda_{\text {max }}: 270 \mathrm{~nm}$ (methanol) ; HREI-MS m/z 193.0142 $[\mathrm{M}+\mathrm{Na}]^{+} ; \mathrm{m} / \mathrm{z} 170.0142[\mathrm{M}]^{+}, \mathbf{C}_{7} \mathbf{H}_{6} \mathbf{O}_{5}$ (calcd 170.0215). ${ }^{13} \mathrm{C}$ NMR (100 MHz, Methanold4): 120.57 (C-1), 108.66 (C-2/C-6), 145.34 (C-3/C-5), 137.91 (C-4), $167.58(\mathrm{C}=\mathrm{O}) .{ }^{1} \mathrm{H}$ NMR (400 MHz, Methanol-d4): 6.97 (H-2 /H$6, \mathrm{~s})$.

Compound 3: Penta-O-galloylglucose ; White powder; HPLC $\mathrm{R}_{\mathrm{t}} 47.30 \mathrm{~min}$; $\mathrm{UV}$ vis $\lambda_{\max }$ : 279 nm (methanol) ; HREI-MS m/z 963.1079 $[\mathrm{M}+\mathrm{Na}]^{+} ; \quad \mathrm{m} / \mathrm{z} \quad 940.1079[\mathrm{M}]^{+}, \quad \mathbf{C}_{\mathbf{4 1}} \mathbf{H}_{\mathbf{3 2}} \mathbf{O}_{\mathbf{2 6}}$ (calcd 940.1182). ${ }^{13} \mathrm{C}$ NMR (100 MHz, Methanol-d4): 121.07 ; 120.38 ; 120.26 ; $120.23 ; 119.75$ (C-1), 110.65; 110.50 ; $110.44 ; 110.41 ; 110.37$ (C-2/C-6), 146.56 ; $146.48 ; 146.45 ; 146.39 ; 146.29$ (C-3/C-5), $140.78 ; 140.37 ; 140.32 ; 140.14 ; 140.03$ (C4), $167.95 ; 167.32 ; 167.04 ; 167.94 ; 167.24$ $(\mathrm{C}=\mathrm{O}), 93.92$ (C1'-gluc), 74.54 (C3'-gluc), 74.20 (C2'-gluc), 72.29 (C5'-gluc), 69.89 (C4'-gluc), 63.23 (C6'-gluc). ${ }^{1} \mathrm{H}-\mathrm{NMR}$ (400 MHz, Methanol-d4): $6.92 ; 6.97 ; 7.00 ; 7.07$; $7.13(\mathrm{H}-2$ /H-6, s), 6.15 (d, J=9.0 Hz, H-1'), 5.82 (d, H-3'), 5.54 (t, J=9.0 Hz, H-2'), 5.51 (m, H-5') et $4.35\left(\mathrm{~m}, \mathrm{H}-4^{\prime}\right)$ et $4.31 / 4.42(\mathrm{dd}$, $\left.\mathrm{J}=10.2 \mathrm{~Hz} / 4.5 \mathrm{~Hz}, \mathrm{H}-6 \mathrm{a}^{\prime} / \mathrm{H}-6 \mathrm{~b}^{\prime}\right)$.

The data on antibacterial activity of compounds $\mathbf{1}$ and $\mathbf{3}$ against variety of Staphylococcus aureus and Pseudomonas aeruginosa is summarized in Table 4.

Table 1: Phytochemical screening of Mangifera indica seed kernel.

\begin{tabular}{lcc}
\hline Phytochemical substances & Tests & Results \\
\hline Flavonoids & Cyanidine & + \\
Tannins & Ferric chloride & ++++ \\
Tanins cath. & Stiasny & - \\
Tanins gall. & Stiasny & +++ \\
Alkaloids & Dragendorff & ++ \\
Terpenoids and steroids & Liberman Buchard & ++ \\
Saponins & Formation of persistent & + \\
Anthraquinones & Ammonium & + \\
\hline \multicolumn{2}{c}{++++ Very appreciable amount, +++: appreciable amount, ++ moderate amount, + : trace, - : absence }
\end{tabular}


Table 2: Results of effectiveness tests of ethanolic extract and ethyl acetate fraction of Mangifera indica seed kernel cake, and antibiotics.

\begin{tabular}{lcccccc}
\hline \multirow{2}{*}{ Bacterial strains } & \multicolumn{7}{c}{ Tested substances } \\
& $\begin{array}{c}\text { Observed inhibition diameter (mm) } \\
\text { extract }\end{array}$ & $\begin{array}{c}\text { AcOET } \\
\text { fraction }\end{array}$ & Ox & Fox & Caz & Imp \\
\hline S. aureus Méti S & 19 & 14 & 43 & 32 & - & - \\
S. aureus Méti $R$ & 15 & 10 & 0 & 0 & - & - \\
S. aureus ATCC 25923 & 16 & - & 28 & 30 & - & - \\
P. aeruginosa Cefta \& Imp.S & 13 & 10 & - & - & 30 & 30 \\
P. aeruginosa Cefta \& Imp.R & 13 & 11 & - & - & 0 & 0 \\
P. aeruginosa ATCC 27853 & - & - & - & - & 26 & 25 \\
\hline
\end{tabular}

Not tested (-); Oxacillin (Ox); Cefoxitin (Fox); Ceftazidime (Caz); Imipenem (Imp). Ethanolic (EtOH) extract; Ethyl acetate (AcOET) fraction

Table 3: UV analysis of ethyl acetate fraction of the Mangifera indica seed kernel.

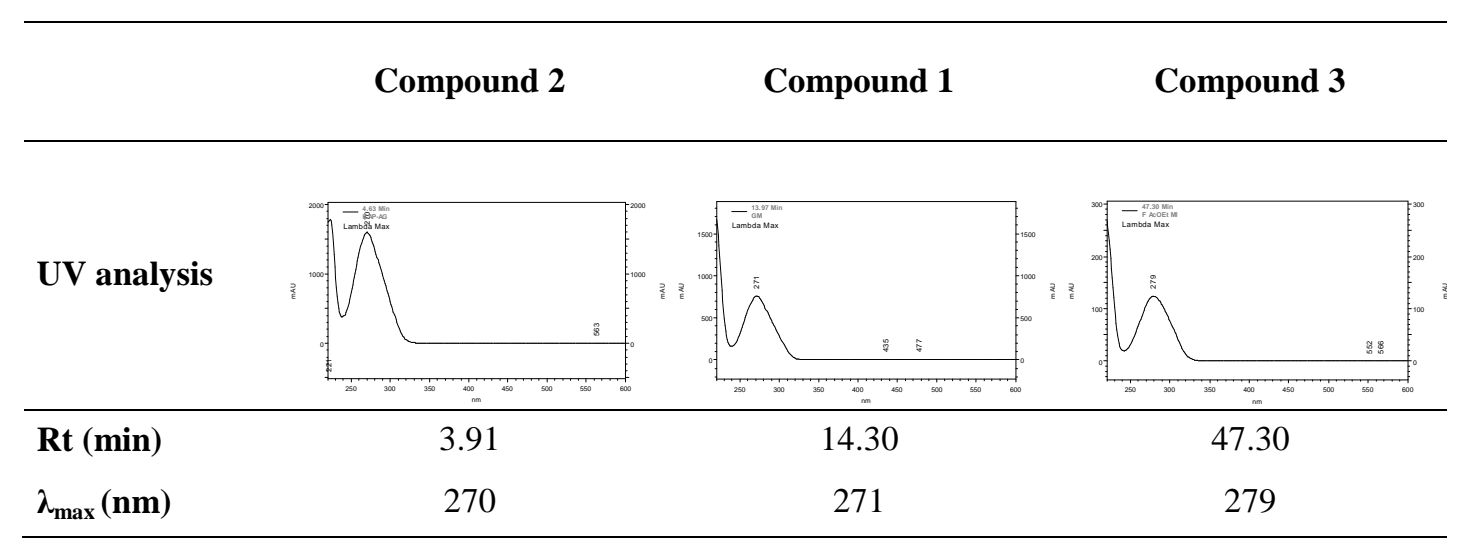


Table 4: Antibacterial activity of compounds isolated from Mangifera indica seed kernel cake.

\begin{tabular}{|c|c|c|c|c|c|c|}
\hline \multirow{2}{*}{ Compounds } & \multicolumn{6}{|c|}{ Microorganism strains (MIC, mg/mL) } \\
\hline & $\mathrm{Sa} \mathrm{S}$ & Sa R & $\mathrm{Sa} \mathrm{AT}$ & $\operatorname{Pa} \mathrm{S}$ & $P a \mathbf{R}$ & Pa AT \\
\hline Gallate de méthyles $\underline{\mathbf{1}}$ & 1.6963 & 1.6963 & 1.6963 & 0.8481 & 1.6963 & 1.6963 \\
\hline Penta- $O$-galloyle-glucoside $\underline{\mathbf{3}}$ & 0.0488 & 0.0488 & 0.0488 & 0.0976 & - & 0.0976 \\
\hline
\end{tabular}

Sa S (Staphylococcus aureus sensitive to methicillin), Sa R (Staphylococcus aureus resistant to methicillin), Sa AT (referenced strains of Staphylococcus aureus ATCC 25923), Pa S (Pseudomonas aeruginosa sensitive to ceftazidime and imipenem), $P a \mathrm{R}$ (Pseudomonas aeruginosa resistant to ceftazidime and imipenem) and $P a$ AT (referenced strains of Pseudomonas aeruginosa ATCC 27853).

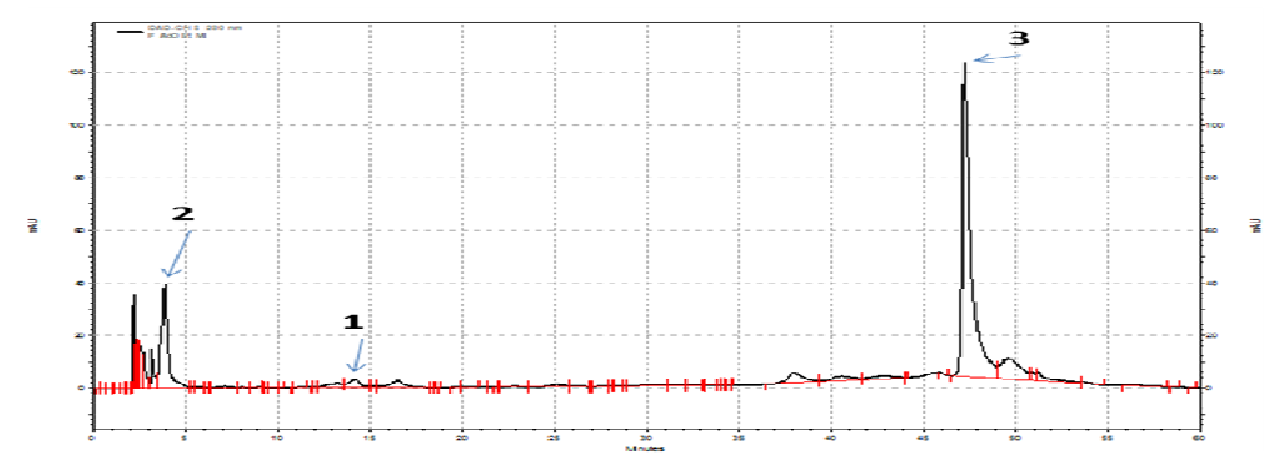

Figure 1: HPLC profiles for the ethyl acetate fraction of Mangifera indica seed kernel, measured at $280 \mathrm{~nm}$.<smiles>COC(=O)c1cc(O)c(O)c(O)c1</smiles>

Compoud 1 (Methyl gallate)<smiles>O=C(O)c1cc(O)c(O)c(O)c1</smiles>

Compoud 2 (Gallic acid)<smiles>O=C(OCC1O[C@H](COC(=O)c2cc(O)c(O)c(O)c2)[C@@H](OC(=O)c2cc(O)c(O)c(O)c2)[C@@H](OC(=O)c2cc(O)c(O)c(O)c2)[C@H]1OC(=O)c1cc(O)c(O)c(O)c1)c1cc(O)c(O)c(O)c1</smiles>

Compoud 3

(Penta- $\mathrm{O}$-galloylglucose)

Figure 2: Structure of compounds isolated from seed kernel cake of Mangifera indica. 


\section{DISCUSSION}

The presence of various active secondary plant metabolites (Harborne, 1998) as revealed by the phytochemical screening (Table 1) supports the resourcefulness of the plant and can justify medicinal properties of mango plant. For example, tannins have antibacterial and antiseptic properties whereas triterpenes and steroids have analgesic and anti-inflammatory effects (Ahmed et al., 2007; Hana et al., 2010). Flavonoids are known to be synthesized by plants in response to microbial infection (Dhanabalan et al., 2008).

The results of this preliminary investigation on the antimicrobial activities indicated that the ethanolic extract and ethyl acetate fraction have significantly sensitive against Staphylococcus aureus with inhibition diameters varying from $15 \mathrm{~mm}$ to $19 \mathrm{~mm}$ and from $10 \mathrm{~mm}$ to $14 \mathrm{~mm}$ respectively. The ethanolic extract and ethyl acetate fraction have moderately sensitive against Pseudomonas aeruginosa with inhibition diameters of $13 \mathrm{~mm}$ and 10-11 $\mathrm{mm}$ respectively. The ethanolic extract is more reactive than ethyl acetate fraction probably because many secondary plant metabolites present in the ethanolic extract have been lost in water during ethyl acetate/water partition operation. Many researches have shown that the ethanolic extract from some plants posses antimicrobial properties (Adegoke et al., 2010; Golly et al., 2012).

The HPLC analysis (Figure 1) of the ethyl acetate fraction Mangifera indica seed kernel from the ethanolic extract of the dried powdered indicated the presence of three (3) major compounds $\mathbf{1}, \mathbf{2}$ and $\mathbf{3}$. A preliminary study of the UV spectra (Table 3) of compounds 1, 2 and $\mathbf{3}$ showed absorbance bands at 271, 270 and $279 \mathrm{~nm}$ respectively, characteristics of phenolic compounds (Soro et al., 2012). The UV, ${ }^{1} \mathrm{H}$ NMR, ${ }^{13} \mathrm{C}$ NMR and EI-MS spectral data with reported values lead to the identification of compound $\mathbf{1 , 2}$ and $\mathbf{3}$ as Methyl gallate (Ekouya et al., 2006; Ekaprasada et al., 2009; Javid et al., 2012), Gallic acid (Korul'kina et al., 2004; Soong et al., 2006) and Penta- $O$-galloylglucose (Cho et al., 2010) respectively (Figure 2).

\section{Compound 1}

Compound 1, isolated as yellow powder, was soluble in methanol. The HREIMS spectrum of compound $\mathbf{1}$ revealed a molecular ion peaks $\mathrm{M}+$ at $\mathrm{m} / \mathrm{z} 184.0271$ corresponding to the molecular formula $\mathbf{C}_{8} \mathbf{H}_{8} \mathbf{O}_{5}$ (calcd 184.0372). The ${ }^{13} \mathrm{C}-\mathrm{NMR}$ spectrum of compound $\mathbf{1}$ showed six carbon signals: the methyl group at $\delta_{\mathrm{C}} 61.68 \mathrm{ppm}(\mathrm{O}-$ $\mathrm{CH}_{3}$ ), two equivalent aromatic carbons at $\delta_{\mathrm{C}}$ $110.02 \mathrm{ppm}$ (C-2/C-6), one carbonyl group at $\delta_{\mathrm{C}} 169.02 \mathrm{ppm}(\mathrm{C}=\mathrm{O})$ and four aromatic carbons at $\delta_{\mathrm{C}} 121.43 \mathrm{ppm}(\mathrm{C}-1), 139.77 \mathrm{ppm}$ (C-4) and $146.51 \mathrm{ppm}$ (C-3/C-5). The comparison of the UV, H-NMR and EI-MS spectra data with reported values leads to the identification of compound $\mathbf{1}$ as Methyl gallate (Ekouya et al., 2006; Ekaprasada et al., 2009; Javid et al., 2012). The compound 1 has been found in the leaves of Toona sureni (Ekaprasada et al., 2009) and in the roots of Conyza canedensis (Javid et al., 2012).

\section{Compound 2}

Compound 2, isolated as white powder, was soluble in methanol. The HREI-MS spectrum of compound 2 revealed a molecular ion peaks $\mathrm{M}+$ at $\mathrm{m} / \mathrm{z} 170.0142$ corresponding to the molecular formula $\mathbf{C}_{7} \mathbf{H}_{6} \mathbf{O}_{5}$ (calcd 170.0215). The ${ }^{13} \mathrm{C}-\mathrm{NMR}$ spectrum of compound 2 showed six carbon signals: two equivalent aromatic carbons at $\delta_{\mathrm{C}} 108.66 \mathrm{ppm}$ (C-2/C-6), one carbonyl group at $\delta_{\mathrm{C}} 167.58$ ppm $(\mathrm{C}=\mathrm{O})$ and four aromatic carbons at $\delta_{\mathrm{C}}$ 120.57 ppm (C-1), $137.91 \mathrm{ppm}$ (C-4) and $145.34 \mathrm{ppm}(\mathrm{C}-3 / \mathrm{C}-5)$. The comparison of the UV, H-NMR and EI-MS spectra data with reported values leads to the identification of compound $\mathbf{2}$ as Gallic acid (Korul'kina et al., 2004; Soong et al., 2006).

\section{Compound 3}

Compound $\mathbf{3}$, isolated as white powder, was soluble in methanol. The HREI-MS spectrum of compound 3 revealed a molecular 
ion peaks $\mathrm{M}+$ at $\mathrm{m} / \mathrm{z} \quad 940.1079[\mathrm{M}]^{+}$, corresponding to the molecular formula $\mathbf{C}_{41} \mathbf{H}_{32} \mathbf{O}_{26}$ (calcd 940.1182). The ${ }^{1} \mathrm{H}-\mathrm{NMR}$ spectrum of compound $\mathbf{3}$ showed five signals characteristic of ten aromatic protons at $\delta_{\mathrm{C}}$ 6.92, 6.97, 7.00, 7.07, 7.13 ppm as singlet and six signals at characteristic of glucose protons at $\delta_{\mathrm{C}} 6.15,5.82,5.54,5.51,4.35$ and $4.31 / 4.42$ ppm. The ${ }^{13} \mathrm{C}-\mathrm{NMR}$ spectrum of compound 3 showed five carbon signals characteristic of carbonyl group of gallic acid at $\delta_{\mathrm{C}} 167.95$, 167.32, 167.04, 167.94, 167.24 ppm $(\mathrm{C}=\mathrm{O})$, five carbon signals characteristic of aromatic C-2/C-6 at $\delta_{\mathrm{C}} 110.65,110.50,110.44,110.41$, $110.37 \mathrm{ppm}$, five carbon signals characteristic of quaternary C-1 of gallic acid at $\delta_{\mathrm{C}} 121.07$, $120.38,120.26,120.23,119.75 \mathrm{ppm}$, five carbon signals characteristic of quaternary aromatic carbon C-3/C-5 of gallic acid at $\delta_{\mathrm{C}}$ 146.56, 146.48, 146.45, 146.39, $146.29 \mathrm{ppm}$, five carbon signals characteristic of quaternary aromatic carbon $\mathrm{C}-4$ of gallic acid at $\delta_{\mathrm{C}} 140.78,140.37,140.32,140.14,140.03$ ppm and six carbon signals characteristic of glucose carbon at $\delta_{\mathrm{C}}(\mathrm{ppm}) 93.92$ (C1'-gluc), 74.54 (C3'-gluc), 74.20 (C2'-gluc), 72.29 (C5'-gluc), 69.89 (C4'-gluc), 63.23 (C6'-gluc) ppm. The COSY spectrum of compound $\mathbf{3}$ showed proton/proton correlations of glucose between H-1'/H-2', H-2'/H-3', H-3'/H-4', H4'/H-5', H-5'/H-6a', H-5'/H-6b' and H-6a'/H$6 b^{\prime}$. The HSQC spectrum of compound $\mathbf{3}$ showed carbon/proton correlations of glucose between C-1'/H-1', C-2'/H-2', C-3'/H-3', C4'/H-4', C-5'/H-5', C-6'/H-6a' and C-6'/H$6 \mathrm{~b}$ '. The comparison of the UV, NMR and EIMS spectra data with reported values leads to the identification of compound $\mathbf{3}$ as Penta- $O$ galloylglucose (Cho et al., 2010).

Compounds $\mathbf{1}$ and $\mathbf{3}$ have shown antibacterial activity against variety of Staphylococcus aureus and Pseudomonas aeruginosa (Table 4). The minimum inhibitory concentration (MIC) of compound 1 was in the range of $1.6963 \mathrm{mg} / \mathrm{mL}$ and 0.8481-1.6963 mg/mL for Staphylococcus aureus and Pseudomonas aeruginosa respectively. The minimum inhibitory concentration (MIC) of compound $\mathbf{3}$ was in the range of $0.0488 \mathrm{mg} / \mathrm{mL}$ and 0.0976 $\mathrm{mg} / \mathrm{mL}$ for Staphylococcus aureus and Pseudomonas aeruginosa respectively. These data revealed that compound $\mathbf{1}$ showed antibacterial activity but lesser when compared to compound 3. These compounds may be responsible to the medicinal properties attribute to Mangifera indica kernel seed cake.

In this study, the phytochemical screening tests of the air-dried kernel seed cake of Mangifera indica revealed appreciable amount of tannins, triterpenes, steroids and alkaloids and traces of flavonoids, saponins, anthraquinones. The antibacterial test consisted in determining the minimum inhibitory concentration (MIC). The results of antibacterial activity studies showed that compounds $\mathbf{1}$ and $\mathbf{3}$ exhibited significantly antibacterial effects against the variety of Staphylococcus aureus with MIC values of 1.6963 and $0.0488 \mathrm{mg} / \mathrm{mL}$ respectively. Compounds $\mathbf{1}$ and $\mathbf{3}$ also showed an antibacterial activity against the variety of Pseudomonas aeruginosa with MIC values of 0.8481 - $1.6963 \mathrm{mg} / \mathrm{mL}$ and $0.0976 \mathrm{mg} / \mathrm{mL}$ respectively. These activities may be due to the presence of different classes of secondary metabolites. For our best knowledge, there are few studies on the plant which established relation between an isolate compound and its antibacterial properties.

\section{ACKNOWLEDGEMENTS}

We express our gratitude to Laboratory SRSN of the University of Poitiers (France) and the Strategic Program of Support to Scientific Research (PASRES) for their material supports and to the Embassy of Côte d'Ivoire in France for the doctoral financial support.

\section{REFERENCES}

Adegoke AA, Iberi PA, Akinpelu DA, Aiyegoro OA, Mboto CI. 2010. Studies on phytochemical screening and antimicrobial potentials of Phyllanthus amarus against multiple antibiotic 
resistant bacteria. International Journal of Applied Research in Natural Products, 3(3): 6-12.

Ahmed A, Saeid D, Eman A. 2007. Egyptian mango by-product 2: Antioxidant and antimicrobial activities of extract and oil from mango seed kernel. Food chemistry, 103: $1141-1152$.

Cho J-Y, Sohn M-J, Lee J, Kim W-G. 2010. Isolation and identification of pentagalloylglucose with broad-spectrum antibacterial activity from Rhus trichocarpa Miquel. Food Chemistry, 123: 501-506.

Dhanabalan R, Doss A, Jagadeeswari M, Balachandar S, Kezia E, Parivuguna V, Josephine RCM, Vaidheki R, Kalamani K. 2008. In vitro Phytochemical Screening and Antibacterial Activity of Aqueous and Methanolic Leaf Extracts of Tridax procumbens against Bovine Mastitis Isolated Staphylococcus aureus. Ethnobotanical Leaflets, 12: 1090-1095.

Djenontin ST, Dangou J, Wotto DV, Sohounlhoue CKD, Losano P, Pioch D. 2006. Composition en Acides Gras, Stérols et Tocophérols de l'huile végétale non conventionnelle extraite des graines de Jatropha Curcas (Euphorbiaceae) du Benin. J. Soc. Ouest-Afr. Chim., 022: 5967.

Ekaprasada MT, Hazll N, Sanusi I, Dachriyanus. 2009. Antioxydant activity of methyl gallate isolated from the leaves of Toona sureni. Indo. J. chem., 9(3): 457-460.

Ekouya A, Itoua BG, Ouabonzi A, Ouamba JM. 2006. Isolement du gallate de méthyle et évaluation de l'activité antibactérienne et antitumorale de quelques extraits de Klainedoxa gabonensis. Phytothérapie, 3: 117-120.

FAO. 2002. Tropical Fruits Projections to 2005. FAO: Rome.

Gabino G, Deyarina G, Cheyla R, Alberto JNS, René D. 2008. Scavenger effect of a mango (Mangifera indica L.) food supplement's active ingredient on free $\begin{array}{lrr}\text { radicals produced } & \text { by } & \text { human } \\ \text { polymorphonuclear } & \text { cells } & \begin{array}{r}\text { and } \\ \text { hypoxanthine-xanthine }\end{array} \\ \begin{array}{l}\text { oxidase } \\ \text { chemiluminescence systems. }\end{array} & \text { Food } \\ \text { Chemistry, 107: } 1008-1014 . & \end{array}$

Golly KJ, Siaka S, Guessennd N, Soro Y, Djama AJ, Dosso M. 2012. Phytochemical assessment and antimicrobial activity of leaves extract of Vernonia colorata (Wild.) Drake on Resistant Germs of Staphylococcus aureus and Pseudomonas aeruginosa. Journal of Chemical and Pharmaceutical Research, 4(5): 2490-2494.

Hana K, Jeong YM, Hyeonji K, Dong-Sun L, Moonjae C, Hyung-Kyoon C, Young SK, Ashik M, Somi KC. 2010. Antioxidant and antiproliferative activities of mango (Mangifera indica L.) flesh an peel. Food Chemistry, 121: 429-436.

Harborne JB. 1998. Phytochemical Methods: a Guide to Modern Techniques of Plant Analysis ( $3^{\text {rd }}$ edn). Chapman and Hall: London; 60-66.

Javid AB, Fa M, Saleem F, Mushtaq AQ, Surrinder K, Razdan TK. 2012. Salicylic acid and Methyl gallate from the roots of Conyza canedensis. International Journal of Chemical and Analytical Science, 3(2): 1305-1308.

Koné WM, Atindehou KK, Kacou-N'douba A, Dosso M. 2006. Assessing Subsaharian Erythrina for Efficacy: Traditional uses, Biological Activities and Phytochemistry. Afr. J. Trad. Compl. Alter. Med., 4: 17-22.

Korul'kina LM, Shul's EE. 2004. Biologically active compounds from Limonium Gmelinii and L. Popovii. Chemistry of Natural Compounds, 40(5): 465-471.

Moroh J-LA, Bahi C, Dje K, Loukou YG, Guédé-Guina F. 2007. Etude de l'activité antimicrobienne de l'extrait acétatique (EAC) de Morinda morindoides (Baker) Milne-Readhead (Rubiaceae) sur la croissance in vitro des souches d'Escherichia coli. Bull. Soc. Roy. Sci. Liège, 77: $44-61$. 
Oussou KR, Yolou S, Boti JB, Guessennd N, Kanko C, Ahibo C, Casanova J. Etude chimique et activité antidiarrheique des huiles essentielles de deux plantes aromatiques de la pharmacopée ivoirienne 2008. Eur. J. Scient. Res., 24(1): 94-103.

Pretsch E, Bühlmann P, Badertscher M. 2009. Structure Determination of Organic Compounds, Tables of Spectral Data (4th revised and enlarged edn). Springer; $p$ 408.

Ribeirio SMR, Barbosa LCA, Queiroz JH , Knödler M, Schieber A. 2008. Phenolic compounds and antioxidant capacity of Brazilian mango. Food Chemistry, 110: 620-626.

Sairam K, Hemalatha S, Ashok K, Srinivasan T, Jai G, Shankar M, Venkataraman S. 2003. Evaluation of anti-diarrhoeal activity in seed extracts of Mangifera indica. Journal of Ethnopharmacology, 84: 11-15.

Soong Y-Y, Barlow PJ. 2006. Quantification of gallic acid and ellagic acid from longan (Dimocarpus longan Lour.) seed and mango (Mangifera indica L.) kernel and their effects on antioxidant activity. Food Chemistry, 97 524-530.

Soro Y, Kassi ABB, Bamba F, Siaka S, Touré SA, Coustard J-M. 2012. Flavonoids and gallic acid from leaves of Santaloides afzelii (Connaraceae). Rasayan J. Chem., 5(3): 332-337.

Sunday SA. 2000. Mango (Mangifera indica) Kernel: Chromatographic Analysis of the Tannin, and Stability Study of the Associated Polyphenol Oxidase Activity. Journal of Food Composition and Analysis, 13: 149-156.

Susan P, Stephen T, Sherry C, Anne M. 2006. Neoplastic Transformation of BALB/3T3 Cells and Cell Cycle of HL-60 Cells are Inhibited by Mango (Mangifera indica L.) Juice and Mango Juice Extracts. Journal of Nutrition, 136: 1300-1304.

Thoshihide K, Hadjime N, Megumi A, Shigeko U, Yoshiharu K, Shun'ichi D. 2000. Caracterization of novel antimicrobial compounds from mango (Mangifera indica L.) kernel seeds. Food Chemistry, 71: 61-66.

Zakaria ZA, Zaiton H, Henie EFP, Jais AMM, Kasthuri D, Thenamutha M , Othman FW, Nazaratulmawarina R, Fatimah CA. 2006. The in vitro Antibacterial Activity of Corchorus olitoriusand Muntingia calabura Extracts. J. Pharm. Toxicol., 1(2): 108-114. 